\title{
Comparing Occupational Therapy Students' Competency Scores: 2:1 versus 1:1 Fieldwork
}

\author{
Marisa Short \\ Community Therapists Inc., Canada \\ Candace Letham \\ Fraser Health Authority, Canada \\ Leanne Currie \\ University of British Columbia, Canada \\ Donna Patricia Drynan \\ University of British Columbia, Canada
}

\begin{abstract}
Fieldwork is essential to occupational therapy students' development of professional competencies. Fieldwork models using student-to-fieldwork educator ratios of 1:1 and 2:1 are widely used, however, quantitative research exploring differences in student competencies between these two models is scarce. The objective of this study was to determine if development of student competencies differ between 2:1 and 1:1 fieldwork models during an occupational therapy educational program. A retrospective study using two years of occupational therapy students' competency ratings by fieldwork supervisors ( $N=95$ students; $N=355$ fieldwork events) was performed. The Competency Based Fieldwork Evaluation for Occupational Therapists tool was used to assess student competencies at each fieldwork rotation ( $n=5$ placements). Independent samples $t$-tests were used to compare students' scores during 1:1 and 2:1 placements. No significant differences were noted in student competencies following participation in 2:1 and 1:1 placements. It was concluded that students are equally well prepared for practice if they have $1: 1$ or $2: 1$ fieldwork experiences.
\end{abstract}

\section{Keywords: clinical competence; competency-based education; fieldwork supervision; occupational therapy; students}

${ }^{*}$ Corresponding Author: Donna Drynan, Department of Occupational Science and Occupational Therapy, University of British Columbia, T325-2211 Wesbrook Mall, Vancouver, BC V6T 2B5, Canada

Journal URL: http://e-learning.coventry.ac.uk/ojs/index.php/pblh

Short, M., Letham, C., Currie, L., and Drynan, D.P. (2017) 'Comparing Occupational Therapy Students' Competency Scores: 2:1 versus 1:1 Fieldwork'. International Journal of Practice-based Learning in Health and Social Care, 5 (1), 1-11

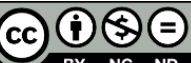

CCY NC ND (C) 2017 Marisa Short, Candace Letham, Leanne Currie, Donna Patricia Drynan. This Open Access article is distributed under the terms of the Creative Commons Attribution Attribution-NonCommercial No Derivatives 4.0 International License (https://creativecommons.org/licenses/by-nc-nd/4.0/ ), which permits unrestricted non-commercial use, distribution, and reproduction in any medium, provided the original work is properly cited and is unaltered. 


\section{Introduction}

Fieldwork is a crucial and necessary aspect of occupational therapy education and training because it provides opportunities for students to consolidate classroom theoretical learning by applying skills within various clinical settings and populations. Fieldwork provides students with opportunities to work alongside a practicing clinician to acquire the professional knowledge, skills, and abilities necessary to become independent clinicians (Canadian Association of Occupational Therapists (CAOT) 2012, Lekkas et al. 2007). There is unquestionable value in fieldwork experience, as it is a fundamental requirement in preparing students to become competent entry-level occupational therapists ( Miller, and Allison 2011).

Historically, the primary model of fieldwork education has one student matched with one fieldwork educator (1:1). A 1:1 model of fieldwork is based on principles of mentorship in which students develop skills individually, relying on their fieldwork educator for guidance (Ladyshewsky, Barrie, and Drake 1998). In 1:1 fieldwork, the fieldwork educator is the expert and controls the content and structure of learning; the student works independently with no interaction with other students (Cohn, Dooley, and Simmons 2002). For the purposes of this article, this will be referred to as the traditional 1:1 model.

Although the traditional 1:1 model is widely used, there is little empirical evidence - and the available evidence is quite dated - to suggest that this model leads to more effective learning outcomes than other models (DeClute and Ladyshewsky 1993). There is also an acknowledged shortage of student fieldwork placements in the healthcare systems due to an increasing number of students, lack of staff, heavy caseloads, and dependency on part-time workers (Copley and Nelson 2012, Martin, Morris, Moore, Sadlo, and Crouch 2004), making traditional $1: 1$ models difficult to sustain.

A growing trend in fieldwork is a collaborative model, in which two or more students work together under the supervision and guidance of one fieldwork educator (2:1, 3:1, etc.). In collaborative fieldwork, the students take on dual roles of teacher and learner, and sharing of learning experiences with their 'co-students' is encouraged (Rindflesch, Dunfee, Cieslak, Eischen, Trenary, Calley, and Heinle 2009). Features of collaborative learning include interdependence, face-to-face interaction and discussion, individual accountability, and focus on group process to promote skill development (Cohn, Dooley, and Simmons 2002). Collaborative fieldwork began to appear in the early 1990s (Mason 1998), and has gained increasing acceptance in recent years (Thomas, Penman, and Williamson 2005) in response to fieldwork placement shortages (Rindflesch et al. 2009). There is also some qualitative evidence that suggests there are increased educational benefits when collaborative models are used, such as superior attainment of student professional competencies (DeClute and Ladyshewsky 1993, Martin et al. 2004, O'Connor, Cahill, and McKay 2012).

Student professional competencies include the knowledge, skills, and abilities required to enact the roles and responsibilities of the practice of occupational therapy (Association of Canadian Occupational Therapy Regulatory Organizations (ACOTRO) 2011, World Federation of Occupational Therapists (WFOT) 2008). The Competency Based Fieldwork Evaluation for Occupational Therapists (CBFE-OT) measures occupational therapy student performance on seven different student professional competencies (Bossers, Miller, Polatajko, and Hartley 2007), and is used in eight out of fourteen occupational therapy programs in Canada. The seven competencies are: i) practice knowledge, ii) clinical reasoning, iii) facilitating change with a practice process, iv) professional interactions and responsibility, v) communication, vi) professional development, and vii) performance management. The tool also includes a global overall rating that is assigned by the supervisor (i.e., this is a separate item and not an average of the seven other items). Evaluation of fieldwork performance provides direction for learning objectives on subsequent fieldwork placements and thus helps to ensure that students demonstrate entry-level professional competencies by the end of their education (Bossers et al. 2007). As students advance through their fieldwork placements, their professional knowledge, 
skills, and abilities progress along a continuum of developmental stages: entry-level student; knowledge application; transition; consolidation and entry-level clinician (Bossers et al. 2007).

Professional competencies develop over time, and fieldwork provides repeated opportunities to apply classroom learning in a variety of real-life clinical settings (Holmes et al. 2010, Ladyshewsky 2010). For this reason, the World Federation of Occupational Therapists (WFOT) (2007 as cited in Holmes et al. 2010) requires all occupational therapy students to accumulate a minimum of 1,000 hours of fieldwork during their training.

Several researchers have used qualitative methods to explore processes and outcomes related to collaborative fieldwork (Bartholomai and Fitzgerald 2007, Dawes and Lambert 2010, Jung. Martin, Graden, and Awrey 1994, Martin et al 2004, O'Connor, Cahill, and McKay 2012, Price and Whiteside 2016, Rindflesch et al. 2009). Collectively, these qualitative studies suggest that students who participate in collaborative fieldwork placements are more able to meet their competency goals during the placement as a result of increased focus on self-directed learning, increased comfort and confidence, shared problem solving, and discussion of assessments and treatment plans. These qualitative studies also highlight that fieldwork educators have concerns about competition between students, increased workload for supervisors, sharing of misinformation between students, and challenges meeting the learning needs of multiple students. Further, students in collaborative fieldwork placements report decreased opportunities for individual feedback and decreased opportunities to demonstrate performance management competencies during higher-level fieldwork placements. (Higher level fieldwork placements refer to senior level or final placements in the program). To our knowledge, in the field of occupational therapy education, no quantitative studies have compared student competencies between traditional 1:1 and collaborative 2:1 fieldwork models.

Therefore, the purpose of this study was to examine the influence of fieldwork education models on student competencies by comparing CBFE-OT scores between students completing traditional 1:1 fieldwork placements with those completing collaborative 2:1 fieldwork placements. Based on the previous qualitative research on collaborative fieldwork experiences, the study hypothesis was that students who complete 2:1 fieldwork placements have higher competency ratings compared to students who complete $1: 1$ fieldwork placements, at each fieldwork level.

\section{Method}

\section{Research design}

This retrospective descriptive study compared professional competency scores of students completing traditional 1:1 fieldwork and students completing collaborative 2:1 fieldwork at each of five fieldwork levels in an entry-level occupational therapy education program. The local university research ethics board approved this study. Informed consent from participants was not required as this study involved the secondary use of de-identified data.

\section{Participants}

A convenience sample of data from 95 students enrolled in an entry-level occupational therapy program in Western Canada was used. Inclusion criteria for this study were: graduation from this program in 2013 or 2014 , and completion of five fieldwork placements within the program. There were no exclusion criteria for this study.

\section{Instruments}

Competency Based Fieldwork Evaluation for Occupational Therapists (CBFE-OT). At the study institution, the fieldwork educator evaluates student performance on each competency at the midpoint and end of each fieldwork experience using the CBFE-OT tool (Bossers et al. 2007). The minimum rating on each scale is ' $U$ ' indicating unacceptable, and the maximum rating on each scale is ' $\mathrm{E}$ ' indicating exceptional. Between the minimum and maximum ratings is a scale 
from 1 to 8 with a higher number indicating a higher competency rating. Fieldwork educators can complete the rating either by typing ratings into a form and then submitting by email, or they can print the form, hand-write the rating and then scan/fax the form. Educators are instructed to assign a numeric score between 1 and 8 and are permitted to include decimal points (e.g., 2.8 or 5.75), and they can also write ' $U$ ' or 'E' (unacceptable or exceptional). For the purposes of this study, ' $U$ ' and 'E' were assigned numeric equivalents of 0 and 9 respectively (Bossers et al. 2007). For each of the seven competencies, students may create specific individual learning objectives, which the fieldwork educator rates on separate competency rating scales.

In the original development of the CBFE-OT tool, 22 clinicians, including occupational therapists, physical therapists, speech-language pathologists, and audiologists from 21 different practice areas, evaluated the face-validity and utility of the tool. Results indicated that it was user-friendly, captured a comprehensive overview of rehabilitation domains, and is sensitive to changes in competence over time (Miller, Bossers, Polatajko, and Hartley 2001). The authors of this study were unable to locate publications reporting the psychometric validation of the CBFEOT.

\section{Procedures}

Students who graduate from the program described in this study complete at least five fieldwork placements as part of the minimum program requirements. Two placements occur in Year One of the program, level 1 (5 weeks) and level 2 (6 weeks). Three placements occur in Year Two of the program, level 3 ( 6 weeks), level 4 (7 weeks), and level 5 (7 weeks). Prior to each placement, students indicate their preference for location, practice area, or both, depending on the placement level. The Fieldwork Coordinator then assigns students to a fieldwork site and fieldwork educator. The process of assigning students is iterative, beginning with random assignment by computer, and then subsequent review and refinement by the Fieldwork Coordinator. Factors considered during refinement of matches include: student education needs with respect to practice area, geographical convenience, and student and fieldwork educator qualities such as communication and learning style. After these factors are considered, students are assigned to a particular fieldwork model (e.g., 1:1, 2:1, 3:1). When assigning students to collaborative fieldwork placements, the Fieldwork Coordinator also considers issues of studentto-student compatibility.

At the study institution, all fieldwork educators and students receive training in fieldwork processes. Fieldwork educators attend a one-day workshop that covers topics including learning styles and scoring the CBFE-OT, and have access to a fieldwork educator blog and one-on-one coaching with the Fieldwork Coordinator. Curriculum content for students includes 'giving and receiving feedback', 'creating learning objectives', and 'professionalism'. The orientation of fieldwork educators and students is the same regardless of fieldwork model. Further, collaborative 2:1 fieldwork placements are implemented in a non-standardized way, such that each fieldwork educator who offers collaborative fieldwork experiences is able to design and implement the rotation as they desire (i.e., the institution does not provide a protocol).

The primary dependent variable of this study was professional competence demonstrated at the end of each fieldwork placement, measured by the fieldwork educator's final evaluation ratings of students using the CBFE-OT. The independent variable was the fieldwork supervision model: traditional 1:1 or collaborative 2:1. Other fieldwork models are used in this setting, but these models were excluded from the study because they were used less frequently (e.g., three students to one educator) or were beyond the scope of the study (e.g., one student to two educators). Following each fieldwork placement, the CBFE-OT rating forms are returned to the school. Program administrators enter the CBFE-OT ratings, student age at admission, cumulative undergraduate grade point average (CGPA), past degree, sex, placement location, practice area, and supervision model into a spreadsheet. During this data entry process, the data are de-identified. For this study, de-identified data for two student cohorts (graduating class 
of 2013 and 2014) were analyzed. The authors of this article, who were students at the time of the study, were not part of the data set.

\section{Data analysis}

Descriptive and comparative statistics were analyzed using SPSS Statistics (IBM ${ }^{\circledR}$ SPSS $®$ Statistics Version 22, New York, USA). Frequencies and means were calculated to describe the entire sample with respect to age at admission, sex, previous degree, and CGPA. Fieldwork placements were grouped by fieldwork model into three groups, 1:1 $(n=314), 2: 1 \quad(n=41)$, and other $(n=109)$. The category other included all models of fieldwork that did not pertain to the research question ( 1 student to 2 educators, $n=91$; 1 student to 3 educators, $n=3$; 1 student to 5 educators, $n=1 ; 2$ students to 0 educators, $n=1 ; 2$ students to 2 educators, $n=10 ; 2$ students to 5 educators, $n=2$; and 3 students to 1 educator, $n=1$ ). These fieldwork placements were excluded from all further data analysis as described above. Fieldwork placements with incomplete CBFE-OT forms were also excluded from further data analysis. The frequency of 1:1 and 1:2 placements were tallied to determine the number of students in each category in terms of supervision style and practice area.

A composite score for professional competence was calculated as the mean of a student's seven CBFE-OT ratings on the final evaluation for each placement. None of the students who had experienced a 2:1 placement had more than one 2:1 placement experience. Each placement episode was treated as an independent event; therefore data were analyzed at the level of placement type, rather than at the individual student level. The global rating scale was highly correlated to the mean score $(r=0.908, p=<0.001)$, and therefore was not used in the analysis.

Figure 1: Derivation of Traditional 1:1 and Collaborative 2:1 groups from all CBFE-OT forms

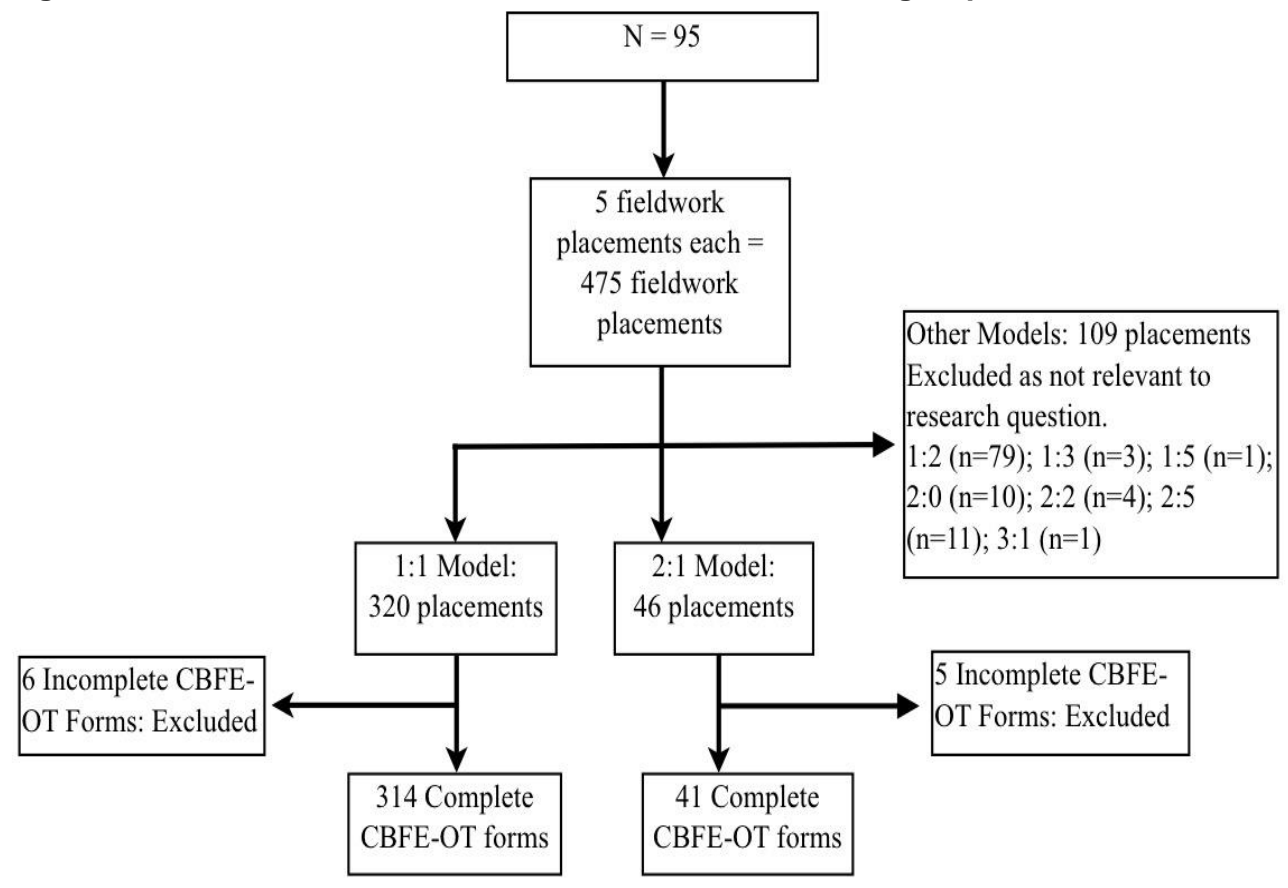

An independent-samples $t$-test was conducted for each placement level to determine whether a difference existed in the mean professional competencies score between the two independent groups (students in traditional 1:1 fieldwork compared to students in collaborative 2:1 fieldwork). A Bonferroni correction was applied $(0.05 / 5)$ to reduce the likelihood of incorrectly identifying a difference when a difference did not exist (i.e., Type I error) resulting from multiple comparisons; therefore, an alpha significance level of 0.01 was used as a cut-off to determine if a test was statistically significant or not (Pallant 2013). 


\section{Results}

We obtained a sample of 95 students. The mean age of the participants was 26.5 years (SD 4.1 , range $21-46) ; 82.1 \%$ of the participants were female $(n=78)$. The mean CGPA of the participants on admission to the program was $80.7 \%$ (SD 3.7, range 72-90). The minimum education for entry to occupational therapy practice in Canada is graduate level, thus all students had at least a previous undergraduate bachelor degree: Thirty-five students had a Bachelor of Science (36.8\%), 32 students had a Bachelor of Arts (33.7\%), 15 students had a Bachelor of Kinesiology (16\%), 4 students had a Bachelor of Health Sciences $(4 \%)$ and 7 students had a Bachelor degree categorized as other (11.6\%). Two students $(2.1 \%)$ had a Master of Science as their highest degree achieved on admission to the program. Each student in the sample completed five fieldwork placements. Figure 1 depicts reasons for excluding data points.

Considering the sample as a whole, most of the placements occurred in General Physical Health $(n=158)$. Other practice areas well represented in the sample included Mental Health $(n$ $=72$ ) and Neurological Systems $(n=46)$. The majority of the traditional 1:1 placements were in General Physical Health $(n=158)$. The second most common traditional 1:1 practice area was Mental Health $(n=70)$. The majority of 2:1 placements were in Student-Led Clinics which are settings where there are typically two or more students assigned to one fieldwork supervisor and the students manage the day-to-day patient care under the oversight of the supervisor. ( $n=$ $31)$. The second most common collaborative 2:1 practice area was 'International' $(n=5)$ - that is, participation in placements that took place outside of Canada (see Table 1).

Table 1: Frequencies of Fieldwork Practice Areas by Fieldwork Level and Fieldwork Model

\begin{tabular}{|c|c|c|c|c|c|c|c|c|c|c|c|}
\hline \multirow[t]{3}{*}{ Practice Area } & \multicolumn{10}{|c|}{$\begin{array}{l}\text { Fieldwork Model by Level } \\
n \text { (\% of group in model) }\end{array}$} & \multirow{3}{*}{$\begin{array}{l}\text { Total } \boldsymbol{n} \\
(\% \\
\text { total) }\end{array}$} \\
\hline & \multicolumn{2}{|c|}{ Level 1} & \multicolumn{2}{|c|}{ Level 2} & \multicolumn{2}{|c|}{ Level 3} & \multicolumn{2}{|c|}{ Level 4} & \multicolumn{2}{|c|}{ Level 5} & \\
\hline & $1: 1$ & $2: 1$ & $1: 1$ & $2: 1$ & $1: 1$ & $2: 1$ & $1: 1$ & $2: 1$ & $1: 1$ & $2: 1$ & \\
\hline $\begin{array}{l}\text { General Physical } \\
\text { Health }\end{array}$ & $\begin{array}{r}46 \\
(63.9)\end{array}$ & & $\begin{array}{r}35 \\
(52.3)\end{array}$ & & $\begin{array}{r}25 \\
(44.7)\end{array}$ & & $\begin{array}{r}21 \\
(39.7)\end{array}$ & & $\begin{array}{r}31 \\
(47.0)\end{array}$ & & $\begin{array}{r}158 \\
(44.5)\end{array}$ \\
\hline International & & & & & & & $\begin{array}{r}1 \\
(1.9)\end{array}$ & $\begin{array}{r}3 \\
(23.1)\end{array}$ & $\begin{array}{r}1 \\
(1.5)\end{array}$ & $\begin{array}{r}2 \\
(40.0)\end{array}$ & $\begin{array}{r}6 \\
(1.7)\end{array}$ \\
\hline Mental Health & $\begin{array}{r}15 \\
(20.8)\end{array}$ & & $\begin{array}{r}13 \\
(19.4)\end{array}$ & & $\begin{array}{r}17 \\
(30.4)\end{array}$ & $\begin{array}{r}2 \\
(20.0)\end{array}$ & $\begin{array}{r}11 \\
(20.7)\end{array}$ & & $\begin{array}{r}14 \\
(21.2)\end{array}$ & & $\begin{array}{r}72 \\
(20.3)\end{array}$ \\
\hline $\begin{array}{l}\text { Neurological } \\
\text { System }\end{array}$ & $\begin{array}{r}8 \\
(11.1)\end{array}$ & $\begin{array}{r}1 \\
(16.7)\end{array}$ & $\begin{array}{r}13 \\
(19.4)\end{array}$ & & $\begin{array}{r}9 \\
(16.1)\end{array}$ & & $\begin{array}{r}9 \\
(17.0)\end{array}$ & & $\begin{array}{r}6 \\
(9.1)\end{array}$ & & $\begin{array}{r}46 \\
(13.0)\end{array}$ \\
\hline $\begin{array}{l}\text { Other Areas of } \\
\text { Direct Service }\end{array}$ & $\begin{array}{r}3 \\
(4.2)\end{array}$ & & $\begin{array}{r}2 \\
(3.0)\end{array}$ & & & & $\begin{array}{r}3 \\
(5.7)\end{array}$ & $\begin{array}{r}2 \\
(15.4)\end{array}$ & $\begin{array}{r}3 \\
(4.5)\end{array}$ & & $\begin{array}{r}13 \\
(3.7)\end{array}$ \\
\hline $\begin{array}{l}\text { Service } \\
\text { Administration }\end{array}$ & & & $\begin{array}{r}1 \\
(1.5)\end{array}$ & & & & $\begin{array}{r}1 \\
(1.9)\end{array}$ & & $\begin{array}{r}1 \\
(1.5)\end{array}$ & & $\begin{array}{r}3 \\
(0.8)\end{array}$ \\
\hline $\begin{array}{l}\text { Student-Led } \\
\text { Clinic }\end{array}$ & & $\begin{array}{r}5 \\
(83.3)\end{array}$ & & $\begin{array}{r}7 \\
(100.0)\end{array}$ & & $\begin{array}{r}8 \\
(80.0)\end{array}$ & & $\begin{array}{r}8 \\
(61.2)\end{array}$ & $\begin{array}{r}2 \\
(3.0)\end{array}$ & $\begin{array}{r}3 \\
(60.0)\end{array}$ & $\begin{array}{r}33 \\
(9.3)\end{array}$ \\
\hline $\begin{array}{l}\text { Vocational } \\
\text { Rehabilitation }\end{array}$ & & & $\begin{array}{r}3 \\
(4.5)\end{array}$ & & $\begin{array}{r}5 \\
(9.0)\end{array}$ & & $\begin{array}{r}7 \\
(13.2)\end{array}$ & & $\begin{array}{r}8 \\
(12.1)\end{array}$ & & $\begin{array}{r}23 \\
(6.5)\end{array}$ \\
\hline Total & 72 & 6 & 67 & 7 & 56 & 10 & 53 & 13 & 66 & 5 & 355 \\
\hline
\end{tabular}

NOTE: Blank Cell indicates no data available 
For both groups at each placement level, the data were normally distributed. Levene's tests indicated that for all five fieldwork levels, equal variances could be assumed between the 1:1 and 2:1 groups. At each level, professional competency scores were slightly lower for the 2:1 fieldwork experiences than for the 1:1 fieldwork experiences (see Table 2). With respect to the research hypothesis, the independent samples $t$-tests indicated no significant difference ( $p>0.01)$ in student professional competency scores between 1:1 and 2:1 fieldwork placements at all fieldwork levels (see Table 2).

Table 2: Difference in CBFE-OT Score between 1:1 and 2:1 Fieldwork Placements at Each Fieldwork Level

\begin{tabular}{|l|l|l|l|l|l|l|l|}
\hline $\begin{array}{l}\text { Fieldwork } \\
\text { Level }\end{array}$ & $\begin{array}{l}\text { Student to } \\
\text { Supervisor } \\
\text { Ratio }\end{array}$ & $\begin{array}{l}\boldsymbol{n}(\% \text { of } \\
\text { level) }\end{array}$ & $\begin{array}{l}\text { CBFE-OT } \\
\text { score } \\
\text { Mean (SD) }\end{array}$ & $\boldsymbol{t}$ & Df & $\boldsymbol{p}$ & $\begin{array}{l}\text { Mean Difference } \\
\text { (95\% CI) }\end{array}$ \\
\hline Level 1 & $1: 1$ & $72(92)$ & $3.4(.86)$ & 1.20 & 76 & .236 & $0.42(-0.28$ to 1.12) \\
\hline Level 2 & $2: 1$ & $6(8)$ & $3.0(.05)$ & & & & \\
\hline & $2: 1$ & $67(91)$ & $5.7(.87)$ & 1.42 & 72 & .160 & $0.48(-0.20$ to 1.16$)$ \\
\hline Level 3 & $1: 1$ & $7(9)$ & $5.2(.62)$ & & & & \\
\hline & $2: 1$ & $56(85)$ & $6.6(.73)$ & 2.52 & 64 & .014 & $0.61(0.12$ to 1.09) \\
\hline Level 4 & $1: 1$ & $53(80)$ & $7.8(.55)$ & 1.14 & 64 & .260 & $0.18(-0.14$ to 0.51$)$ \\
\hline & $2: 1$ & $13(20)$ & $7.7(.40)$ & & & & \\
\hline Level 5 & $1: 1$ & $66(93)$ & $8.1(.30)$ & 1.75 & 69 & .085 & $0.25(-0.04$ to 0.53) \\
\hline & $2: 1$ & $5(7)$ & $7.9(.34)$ & & & & \\
\hline
\end{tabular}

\section{Discussion}

To the authors' knowledge, this is the first quantitative study to examine the difference in student professional competency scores between traditional 1:1 and collaborative 2:1 fieldwork models using the CBFE-OT, a widely used outcome measure in Canada. No significant differences in professional competencies scores were found between students completing traditional 1:1 and students completing collaborative 2:1 fieldwork placements at any level. These findings refute our original hypothesis that students completing collaborative 2:1 fieldwork placements would achieve significantly higher competency scores. While it has been reported that students in collaborative 2:1 fieldwork placements practice techniques collaboratively, share previous experiences, discuss clinical reasoning, and feel more confident 
(Martin et al. 2004), this study finds no objective differences in their demonstrated professional knowledge, skills and abilities compared to students completing traditional 1:1 fieldwork.

We were surprised to find that the mean scores at each of the levels were lower for the collaborative 2:1 group compared to the traditional 1:1 group. It is possible that this was related to the small sample sizes in the collaborative 2:1 group. The small collaborative 2:1 sample size reduces the statistical power of the study, which decreases the ability to detect a statistically significant difference (i.e., increasing the likelihood for a Type II error, or false negative result). Further, with such few participants in the collaborative 2:1 groups, each data point will have a larger influence on the mean, compared to the traditional 1:1 group. As stated in the results section, visual inspection of the data and Levene's tests suggest normal distribution of the professional competencies scores, however it is possible that our sample was too small to be truly representative of collaborative 2:1 fieldwork placements.

Another possible reason for the lower scores in the 2:1 group, is that the collaborative fieldwork placements in this study were largely in Student-Led clinics (75.6\% of 2:1 group) and International placements (12.2\% of 2:1 group), where greater autonomy may be expected of students. Some evaluation features of these practice areas could be influencing the CBFE-OT scores, such as who completes the CBFE-OT (peers evaluating each other or other health care professionals who are not occupational therapists); however no data about the evaluation features of these practice areas was available for analysis in this study.

In this study, implementation of collaborative 2:1 placements was non-standardized. This type of implementation of collaborative fieldwork is commonplace. Fieldwork educators often agree to host two students in response to increasing requests for fieldwork opportunities from universities, with little focus on enhancing the student learning outcomes through collaboration (Dawes and Lambert 2010). Research on collaborative learning suggests that placing two students in the same learning environment does not ensure collaboration (Kirschner, Paas, and Kirschner 2008). For successful collaboration, it is important to clarify expectations early (Bartholomai and Fitzgerald 2007) and establish mutual goals and learning objectives (Cohn, Dooley, and Simmons 2002, Ladyshewsky et al. 1998).

In today's pressured health care systems, it is challenging for Fieldwork Coordinators to identify ample occupational therapy fieldwork placement opportunities to meet the current educational demands. One solution to this shortage is to build capacity with collaborative 2:1 fieldwork placements, in which two students share the caseload of one fieldwork educator. Both students and fieldwork educators may have concerns that collaborative 2:1 placements impact individual learning outcomes. For example, the fieldwork educator may focus more of their time and resources on the student with less knowledge, skills, and abilities, thus reducing learning opportunities for the other student (Dawes and Lambert 2010). This study, however, finds no objective differences in student demonstration of professional competencies following collaborative 2:1 or traditional 1:1 fieldwork, at any level. Even without standardized collaborative fieldwork training and implementation processes, and in emerging practice areas (e.g., Student-Led Clinics and International placements), students completing collaborative 2:1 fieldwork earned comparable competency scores compared to students completing traditional 1:1 fieldwork. Thus students and fieldwork educators alike can be reassured that collaborative 2:1 fieldwork offers a unique fieldwork learning experience that does not negatively impact on the students' development of occupational therapy knowledge, skills, and abilities.

\section{Limitations}

There are several limitations to our study. One school provided all of the data, which limits the generalizability of the findings to all entry-level occupational therapy students. The study was retrospective, thus there were a number of aspects that could not be changed. For example, the sample size for the collaborative 2:1 group was limited as only two years of data was available. A larger collaborative 2:1 sample would have allowed further analysis, such as exploring 
whether CGPA or previous degrees predict performance on fieldwork. To avoid excessive multiple comparisons, a composite score was created to address the research question at all five fieldwork levels. This limits our findings and possible interpretations that could be gained from comparing the traditional 1:1 and collaborative 2:1 models on each of the seven competencies.

\section{Future research}

To further contribute to evidence-based education of occupational therapists, more rigorous studies that investigate the development of professional competencies during traditional 1:1 and collaborative 2:1 fieldwork are warranted. These studies should standardize the implementation of collaborative fieldwork using a published protocol such as in Jung et al. (1994) or Rindflesch et al. (2009). A larger collaborative 2:1 sample size, and balanced 1:1 and 2:1 groups, would be necessary. Additional information about the students and fieldwork educators, such as past experience, could be collected and analyzed to rule out possible confounding variables. Future research could also examine competency scores for other types of placement ratios (e.g., placements with one student and two fieldwork educators). Furthermore, as Student-Led clinics contributed a large portion of our collaborative 2:1 fieldwork placements, it is warranted to investigate this practice area, comparing it to other collaborative 2:1 fieldwork placements.

\section{Implications for occupational therapy practice}

This study has the following implications for fieldwork education of entry-level occupational therapists:

- No significant differences were found in development of professional competencies following traditional and collaborative models of fieldwork;

- Fieldwork educators and students should not be deterred from participating in collaborative 2:1 fieldwork placements due to concerns about student development of occupational therapy knowledge, skills, and abilities.

\section{Conclusion}

Collaborative fieldwork models are increasingly employed in occupational therapy entry-topractice education. Potential barriers to establishing collaborative fieldwork placements include student and fieldwork educator concerns about competition between students, increased workload, challenges meeting the learning needs of two students, and decreased opportunities for individual feedback (Bartholomai and Fitzgerald 2007, Dawes and Lambert 2010, Jung et al. 1994, Martin et al. 2004, O'Connor, Cahill, and McKay 2012, Rindflesch et al. 2009). This study however, found no significant difference in demonstration of professional competencies between collaborative 2:1 and traditional 1:1 fieldwork placements at any level. Thus, fieldwork educators and students should not be deterred from collaborative fieldwork due to concerns about learning outcomes. Further research, including randomized control trials should be considered to further explore this area of knowledge. This novel quantitative study contributes to knowledge about the efficacy of different fieldwork models, fostering evidence-based practice in education of future occupational therapists.

\section{Acknowledgements}

The authors would like to acknowledge the staff of the Department of Occupational Science and Occupational Therapy at the University of British Columbia for their support in this project. 


\section{References}

Association of Canadian Occupational Therapy Regulatory Organizations (2011) Essential Competencies of Practice for Occupational Therapists in Canada. [online] 3rd edn. Victoria, BC: College of Occupational Therapists of British Columbia. available from http://www.cotbc.org/PDFs/EssentialCompetenies3rdEd WebVersion.aspx [20 May 2016]

Bartholomai, S. and Fitzgerald, C. (2007) 'The collaborative model of fieldwork education: Implementation of the model in a regional hospital rehabilitation setting'. Australian Occupational Therapy Journal, 54 (s1), S23-S30 https://doi.org/10.1111/j.14401630.2007.00702.x

Bossers, A., Miller, L.T., Polatajko, H., and Hartley, M. (2007) Competency Based Fieldwork Evaluation for Occupational Therapists. Toronto: Nelson Education

Canadian Association of Occupational Therapists (CAOT) (2012) Association of Canadian Occupational Therapy University Programs \& Canadian Association of Occupational Therapists Position Statement: Professional responsibility in fieldwork education in occupational therapy. [online]. Ottawa: CAOT. available from https://www.caot.ca/pdfs/positionstate/fieldwork\%20education\%20\%20Position\%20Stat ement\%20Final\%202012.pdf [19 July 2016]

Cohn, E.S., Dooley, N.R., and Simmons, L.A. (2002) 'Collaborative learning applied to fieldwork education'. Occupational Therapy in Health Care, 15 (1-2), 69-83

https://doi.org/10.1080/J003v15n01 08

Copley, J. and Nelson, A. (2012) 'Practice educator perspectives of multiple mentoring in diverse clinical settings'. British Journal of Occupational Therapy, 75 (10) 456-462 https://doi.org/10.4276/030802212X13496921049662

Dawes, J. and Lambert, P. (2010) 'Practice educators' experiences of supervising two students on allied health practice-based placements'. Journal of Allied Health [online] 39 (1), 20 27 available from http://www.ncbi.nlm.nih.gov/pubmed/20217003 [19 July 2016]

DeClute, J. and Ladyshewsky, R. (1993) ‘Enhancing clinical competence using a collaborative clinical education model'. Physical Therapy [online] 73 (10), 683-689 available from https://doi.org/10.1093/pti/73.10.683 [6 March 2017]

Holmes, J.D., Bossers, A.M., Polatajko, H.J., Drynan, D.P., Gallagher, M., O'Sullivan, C.M. ... and Denney, J. (2010). '1000 fieldwork hours: Analysis of multi-site evidence'. Canadian Journal of Occupational Therapy, 77, 135-143 https://doi.org/10.2182/cjot.2010.77.3.2

Jung, B., Martin, A., Graden, L., and Awrey, J. (1994) 'Fieldwork education: A shared supervision model'. Canadian Journal of Occupational Therapy, 61 (1), 12-19 https://doi.org/10.1177/000841749406100105

Kirschner, F., Paas, F., and Kirschner, P.A. (2008) 'A cognitive load approach to collaborative learning: United brains for complex tasks'. Educational Psychology Review, 21 (1), 3142 https://doi.org/10.1007/s10648-008-9095-2

Ladyshewsky, R.K. (2010) 'Building competency in the novice allied health professional through peer coaching'. Journal of Allied Health [online] 39 (2), e77-82 available from http://www.ncbi.nlm.nih.gov/pubmed/20539925 [20 May 2016] 
Ladyshewsky, R.K., Barrie, S.C., and Drake, V.M. (1998) 'A comparison of productivity and learning outcome in individual and cooperative physical therapy clinical education models'. Physical Therapy, [online] 78 (12), 1288-1298 available from http://www.ncbi.nlm.nih.gov/pubmed/9859948 [19 July 2016]

Lekkas, P., Larsen, T., Kumar, S., Grimmer, K., Nyland, L., Chipchase, L., ... and Finch, J. (2007) 'No model of clinical education for physiotherapy students is superior to another: A systematic review'. Australian Journal of Physiotherapy, 53 (1), 19-28 http://dx.doi.org/10.1016/S0004-9514(07)70058-2

Martin, M., Morris, J., Moore, A., Sadlo, G., and Crouch, V. (2004) 'Evaluating practice education models in occupational therapy: Comparing 1:1, 2:1 and 3:1 placements'. British Journal of Occupational Therapy, 67 (5), 192-200 https://doi.org/10.1177/030802260406700502

Mason, L. (1998) 'Fieldwork education: Collaborative group learning in community settings'. Australian Occupational Therapy Journal, 45 (4), 124-130 https://doi.org/10.1111/j.1440-1630.1998.tb00793.x

Miller, L.T., Bossers, A.M., Polatajko, H.J., and Hartley, M. (2001) 'Development of the competency based fieldwork evaluation (CBFE)'. Occupational Therapy International, 8 (4), 244-262 https://doi.org/10.1002/oti.149

O'Connor, A., Cahill, M., and Mckay, E.A. (2012) 'Revisiting 1:1 and 2:1 clinical placement models: Student and clinical educator perspectives'. Australian Occupational Therapy Journal, 59 (4), 276-283 https://doi.org/10.1111/j.1440-1630.2012.01025.x

Pallant, J. (2013) SPSS Survival Manual. 5th edn. Maidenhead: Open University Press/McGraw-Hill

Price, D. and Whiteside, M. (2016) 'Implementing the 2:1 student placement model in occupational therapy: Strategies for practice', Australian Occupational Therapy Journal 63 (2), 123-129 https://doi.org/10.1111/1440-1630.12257

Rindflesch, A.B., Dunfee, H.J., Cieslak, K.R., Eischen, S.L., Trenary, T., Calley, D.Q. and Heinle, D.K. (2009) Collaborative model of clinical education in physical and occupational therapy at the Mayo Clinic'. Journal of Allied Health, [online] 38 (3), 132 142 available from http://www.ncbi.nlm.nih.gov/pubmed/19753424 [20 May 2016]

Rodger, S., Fitzgerald, C., Davila, W., Millar, F., and Allison, H. (2011) 'What makes a quality occupational therapy practice placement? Students' and practice educators' perspectives'. Australian Occupational Therapy Journal, 58 (3), 195-202 https://doi.org/10.1111/j.1440-1630.2010.00903.x

Thomas, Y., Penman, M., and Williamson, P. (2005) 'Australian and New Zealand fieldwork: Charting the territory for future practice'. Australian Occupational Therapy Journal, 52 (1), 78-81 https://doi.org/10.1111/i.1440-1630.2004.00452.x

World Federation of Occupational Therapists (WFOT) (2008) Entry-level competencies for occupational therapists [online]. Forrestfield, WA: WFOT. available from http://www.wfot.org/ResourceCentre/tabid/132/did/271/Default.aspx [6 March 2017] 